\title{
GLOSSARY OF FINANCIAL MANAGEMENT TERMS
}

- Absorption: the sharing of the costs of a cost center among the products that use the cost center

- Accelerating depreciation: a method of computing depreciation, such as the "sum of the year's digits" or "double declining balance," in which the asset loses value more rapidly than would occur by the "straight line" depreciation method

- Account: a record in a double-entry system that is kept for each (or each class) asset, liability, revenue, and expense

- Accounting: the field that comprises accurate bookkeeping, financial report preparation, as well as the proper interpretation of the financial data and reports of a business

- Accounting equation: an expression of the equivalence, in total, assets = liabilities + ALF stockholder's equity; this is the basic foundation for the balance sheet and income statement that comprises "double-entry accounting"

- Accounting period: that time period, typically 1 year, to which financial statements are related; it can also refer to a month or a quarter of the year (3) months

- Accounting policies: the specific accounting bases selected and followed by a business enterprise (e.g., straight-line or reducing balance depreciation)

- Accounting rate of return: a ratio sometimes used in investment appraisal based on profits, not cash flows

- Accounting standards: prescribed methods of accounting using the accounting standards or financial reporting standards regulation body in your jurisdiction; it is also considered to be a standard collection or rules, laws, and conventions that determine how accounting transactions are recorded as well as how they are presented in the financial statements

- Accounts payable: the amount of monies owed to vendors for either physical goods or services purchased on credit

- Accounts receivable collection report: a table or spreadsheet that depicts the assisted living community's outstanding accounts receivables by the length of time (days, months) that have not been paid and need to be collected

- Accounts receivable turnover ratio: used in ratio analysis to determine the efficiency of how the assisted living facility utilizes its assets; here, the receivables turnover is an indication of how quickly the facility collects on its resident's rent owed; it can be expressed as rent charges to resident's accounts during a given period divided by the amount of accounts receivables

- Accruals: that which has accrued, accumulated, grown; refers to expenses that have been consumed or enjoyed but that have not been paid for at the accounting date 
- Accruals convention: the convention that revenues and costs are matched with one another and dealt with in the profit and loss (P\&L) account of the period to which they relate irrespective of the period of receipt or payment

- Accumulated depreciation: that part of the original cost of a fixed asset that has been regarded as a depreciation expense in successive profit and loss (P\&L) accounts: cost less accumulated depreciation = net book value; this is also considered the cumulative depreciation expense to date, or the total portion of the original cost of the ALC depreciable assets that have already been allocated to depreciation expense in the prior and current period

- Acid test: the ratio of current assets (excluding stock) to current liabilities; also known as the "quick rate or quick current ratio" and measures the immediate solvency or debt-paying ability of a company

- Acquisitions: operations of a reporting entity that are acquired in a period; separate disclosure of turnover, profits, etc., must be made

- Adjusting entry: a journal entry to the general ledger that is necessary to adjust the book account balances to conform with the actual balances and accrual basis at the end of accounting periods

- Aging schedule: table that separates and categorizes resident accounts according to the length of time (days, weeks, months) they are outstanding

- Allocation: the charging of discrete, identifiable costs to cost centers or cost units; a cost is allocated when it is unique to a particular cost center

- Allowable charge: the maximum fee that a third-party payer (state Medicaid and a longterm care insurer) has negotiated with the facility to reimburse for resident care

- Amortization of debts: the repayment of a debt (e.g., bank loan, mortgage) by the facility over a period of time by making regular payments of the principal and interest; this is another word for depreciation; commonly used for depreciation of the capital cost of acquiring leasehold property

- Apportionment: the division of costs among two or more cost centers in proportion to estimated benefit on some sensible basis; apportionment is used for shared costs

- Asset value: a term that expresses the money amount of assets less liabilities of a company attributable to one ordinary share

- Assets: resources of value owned by a business entity

- Assets turnover ratio: a ratio that purports to measure the intensity of use of business assets; calculated as sales over net operating assets; can be expressed as sales as a percentage of net operating assets; asset turnover ratios also provide information on how efficiently the assisted living facility utilizes its assets; they are sometimes referred to as efficiency ratios, asset utilization ratios, or asset management ratios; two commonly used asset turnover ratios are the accounts receivable turnover ratio and the inventory turnover

- Auditing: the independent examination of, and expression of an opinion on, the financial statements of an enterprise by an appointed auditor or accountant in pursuance of that appointment and in compliance with any relevant statutory obligation

- Auditors: outside independent accountants that are either an outside independent accounting firm (e.g., Ernst \& Young, LLP) or certified professional accountants (CPAs) hired by the assisted living facility in order to cross-check the accuracy of the facility's bookkeepers to ensure that the ALC's financial statements are accurate 
Avoidable costs: the specific costs of an activity or sector of a business that would be avoided if that activity or sector did not exist

- Bad debts: debts known to be irrecoverable and therefore treated as losses by inclusion in the profit and loss (P\&L) account as an expense

- Balance sheet: a financial statement showing the financial position of a business entity in terms of assets, liabilities, and capital at a specified date

- Bank statement: financial statement produced by bank to checking and savings accounts depicting deposits, expenses, balances, interest earned, and any service fees

- Bankruptcy: a legal status imposed by a court; usually a trustee is appointed to receive and realize the assets of the bankrupt and to distribute the proceeds to his creditors according to the law

- Benefits in kind: things or services supplied by a company to its directors and others in addition to cash remuneration; a good example is the provision of and free use of a motor vehicle; the value of benefits in kind is taxable

- Bidding: the facility requesting responses from vendors to their written specifications for goods (e.g., cleaning supplies) or services (e.g., outside auditor)

- Bill of lading: a document issued by a carrier to a shipper upon acceptance of goods for shipment that represents a receipt for the goods and the contract stating the terms of carriage

- Board-designated funds: unrestricted funds set aside by the facility's governing board (e.g., corporation's board of directors) for specific purposes

- Bond: a formal written document that provides evidence of a loan; it is a written promise by issuing entity (e.g., United States, state and local governments, corporations like assisted living company, etc.) under legal seal to repay a sum of monies (principal and interest) at some specific time in the future

- Book value: the amount at which an asset is carried on the accounting records and balance sheet; the usual book value for fixed assets is cost less accumulated depreciation; alternative terms include written-down value, net book value, and carrying value; book value rarely if ever corresponds to sellable value

- Break-even chart: a chart that illustrates costs, revenues, profit, and loss at various levels of activity within a relevant range

- Break-even point: the level of activity (e.g., level of sales) at which the business makes neither a profit nor a loss (i.e., where total revenues exactly equal total costs)

- Budget: a formal quantitative expression of management's plans or expectations; master budgets are the forecast or planned profit and loss account and balance sheet; subsidiary budgets include those for sales, output, purchases, labor, cash, etc.

- Capital: an imprecise term meaning the "whole quantity of assets less liabilities owned by a person or a business"; it refers to the funds used in a business

- Capital allowances: deductions from profit for fixed asset purchases; in effect, capital allowances are a standard system of depreciation used instead of depreciation for tax purposes only

- Capital budgeting: the process of planning or appraising possible fixed asset acquisitions

- Capital employed: a term describing the total net assets employed in a business; various definitions are used, so beware when talking at cross-purposes 
- Capital expenditure: expenditure on fixed assets that is chargeable to an asset account when the asset acquired has an estimated life in excess of 1 year and is not intended for sale in the normal running of the business operations

- Capital structure ratios: financial ratios showing the relationship of long-term debt to total assets or to capital/equity

- Cash: strictly coins and notes but used also to mean all forms of ready money, including bank balances

- Cash disbursement journal: records the expenditures of cash

- Cash discount: a reduction in the amount payable by a debtor to induce prompt payment (equivalent to settlement discount)

- Cash flow: a vague term (compare cash flow difficulties) used for the difference between total cash in and total cash out in a period

- Cash-flow forecast: a document detailing expected or planned cash receipts and outgoings for a future period

- Cash-flow statement: a formal financial statement showing a summary of cash inflows and outflows under certain required headings

- Chart of accounts: the complete listing of names of the accounts in the general ledger

- Coinsurance clause: an insurance policy clause that limits the liability of the insurance company to a determinable percentage of the medical loss suffered by the resident (insured)

- Committed costs: those fixed costs that cannot be eliminated or even cut back without having a major effect on the enterprise's activities (e.g., rent)

- Composition ratios: indicate the relationships between various types of assets and current or total assets

- Conservatism: (also known prudence) the convention whereby revenue and profits are not anticipated, but provision is made for all known liabilities (expenses and losses) whether the amount of these is known with certainty or is a best estimate; sssentially:future profit, wait until it happens-future loss, count it

Consideration: the amount to be paid for anything sold, including businesses; may be cash, shares or other securities

- Consistency: convention that there is consistency of accounting treatment of like items within each year and from year to year

Consolidation: the aggregation of the financial statements of the separate companies of a group as if they were a single entity

- Contingent liabilities: possible future debts that may arise due to some future event that is considered possible but not probable

- Contra account: an auxiliary account that is an offset to a related account (i.e., allowance for uncollectable accounts offset resident accounts receivable)

- Contractual discount: the uncollectable difference between the amount the facility charges for its services and the reduced/lower amount the facility has agreed to accept as reimbursement for either Medicaid/long-term care insurer

- Contributed capital: amounts paid into the assisted living facility by investors

- Contribution: a term used in marginal costing-the difference between sale price and associated variable costs 
- Contribution clause: an insurance policy clause that limits the liability of the issuer to a pro rata portion of a loss of property insured by more than one company

- Control account: a general ledger account, the detail of which is contained in a subsidiary ledger (e.g., accounts receivable)

- Controllable costs (also known as managed costs): costs, chargeable to a budget or cost center, which can be influenced by the actions of the persons in whom control is vested

- Controller: the title usually given to the financial management executive responsible for the accounting function within the facility; this position usually reports to the chief financial officer (CFO) of the assisted living facility

- Conversion cost: the cost of bringing a product or service into its present location or condition; may include a share of production overhead

- Convertible loan stock: loans that, at the option of the lender, can be converted into ordinary shares at specified times and specified rates of conversion

- Corporation: business concern formed by a group of individuals, using a legal structure provided by law, possessing a "life of its own" so to speak, independent of the individual owners or investors

- Cost basis: the use of historical, objectively determined cost as the basis of accounting for most assets

- Cost behavior: the change in a cost when the level of output changes

- Cost center: a location, function, or item of equipment in respect of which costs may be ascertained and related to cost units

- Cost control: the attempt to maintain actual costs at, or below, budgeted levels

- Cost convention: the accounting convention whereby balance sheet assets are mostly valued at input cost or by reference to input cost

- Credit: commonly used to refer to a benefit or gain, also the practice of selling goods and expecting payment later

- Credit control: those measures and procedures adopted by a firm to ensure that its credit customers pay their accounts

- Creditors: those persons, firms, or organizations to whom the enterprise owes money

- Creditors payment or settlement period: a ratio (usually creditors/ inputs on credit in a year $\mathrm{x} 365$ ) that measures how long it takes the firm to pay its creditors

- Current assets: cash plus those assets (stock, debtors, prepayments, bank accounts) that the management intend to convert into cash or consume in the normal course of business within 1 year or within the operating cycle

- Current cost accounting (CCA): a system of accounting that recognizes the fluctuating value of money by measuring current value by applying specific indices and other devices to historical costs

- Current liabilities: debts or obligations that will be paid within 1 year of the accounting date; another term used to describe this is creditors: the amount falling due within 1 year

- Current ratio: the ratio of current assets to current liabilities

- Cut-off: the difficulties encountered by accountants in ensuring all items of income and expense are correctly ascribed to the right annual profit statement

- Day's revenue in receivable: the average number of days of billings in accounts receivable and uncollected at a given point in time 
- Debenture: a document that creates or acknowledges a debt; commonly used for the debt itself

- Debit: amount shown in the left side of a T-account, increasing assets and expense accounts and decreasing owner's equity and liability

Debt: a sum due by a debtor to his creditor; commonly used also as a generic term for borrowings

Debt-to-equity ratio: long-term liabilities divided by total assets; it should be noted that debt-to-equity ratio of 0.5 or better is considered good

Debtors: those who owe money

- Debtors payment (settlement) Period: a calculation of the average time taken by credit customers to pay for their goods; calculated by debtors/credit sales in a year x 365

- Depletion method: a method of depreciation applicable to wasting assets such as mines and quarries; the amount of depreciation in a year is a function of the quantity extracted in the year compared to the total resource

- Depreciation: a measure of the wearing out, consumption, or other loss of value whether arising from use, passage of time or obsolescence through technology and market changes; depreciation should be allocated to an accounting period so as to charge a fair proportion to each accounting period during the expected useful life of the asset

- Direct costs: those costs comprising direct materials, direct labor, and direct expenses which can be traced directly to specific jobs, products, or services

- Discontinued operations: operations of the reporting entity that are sold or terminated in a period; turnover and results must be separately disclosed

Discount: a monetary deduction or reduction. Settlement discount (also known as cash discount) is given for early settlement of debts; debentures can be redeemed at a discount; trade discount is a simple reduction in price given to favored customers for reasons such as status or bulk purchase

Discounted cash flow: an evaluation of the future cash flows generated by a capital investment project, by discounting them to their present value

- Discounting of receivables: a method of short-term financing in which resident receivables are used to secure a loan (which is less than the face amount of the receivables) from a financial institution; also known as factoring

- Discretionary costs: expenses such as advertisement, sales promotions, donations, etc.

- Dividend: a distribution of earnings to its shareholders by a company

- Dividend cover: a measure of the extent to which the dividend paid by a company covered by its earnings (profits)

- Dividend policy ratios: this provides insight into the dividend policy of the assisted living facility as well as its prospects for future growth; two commonly used ratios are the dividend yield ratioand the payout ratio

- Dividend yield: a measure of the revenue earning capacity of an ordinary share to its holder; calculated by dividend per share as a percentage of the quoted share price

- Double-entry accounting: a system of recording both the debit and credit aspect of each transaction

- Earnings: another word for profits, particularly, company profits 
- Earnings per share: an investor ratio, calculated as after tax profits from ordinary activities/ number of shares

- Equity: the ordinary shares or risk capital of an enterprise

- Equity convention: the convention that a business can be viewed as a unit that is a separate entity and apart from its owners and from other firms

- Equity financing: raising funds by issuing capital stock, or ownership shares in the assisted living facility

- Exceptional items: material items that derive from events or transactions that fall within the ordinary activities of the reporting entity and that need to be disclosed by virtue of their size or incidence if the financial statements are to give a true and fair view; examples are profits or losses on termination of an operation, costs of a fundamental reorganization and profits and losses on disposal of fixed assets

- Expense: a cost that is in the profit and loss (P\&L) account of a year; it is the cost of operating a business, including capital, administrative and other operating expenditures

- Exposure draft: a document issue on a specific accounting topic for discussion

- Extraordinary items: material items possessing a high degree of abnormality that arise from events or transactions that fall outside the ordinary activities of the reporting entity and that are not expected to recur; they should be disclosed but are very rare

- Factoring: the sale of debtors to a factoring company to improve cash flow; factoring is a method of obtaining finance tailored to the amount of business done; factoring companies also offer services such as credit worthiness checks, sales and debtor recording, and debt collection

- FICA: Federal Insurance Contributions Act, commonly known as Social Security

- FIFO (first in, first out): A method of recording and valuation of fungible assets, especially stocks, thatvalues items on the assumption that the oldest stock is used first; FIFO stocks are valued at most recent input prices

- Finance lease: a leasing contract that transfers substantially all the risks and rewards of ownership of an asset to the lessee; in effect the lessee is really buying the assets with the aid of a loan and the lease installments are really payments of interest and repayments of capital; they are accounted for as such in accordance with the accounting convention of substance over form

- Financial leverage ratio: provides information of the long-term solvency of the assisted living facility; dssimilar to liquidity ratios that focus on short-term assets and liabilities, financial leverage ratios measure the extent to which the assisted living community is utilizing its long-term debt; two primary financial leverage ratios are the debt ratioand the times interest earned ratio

- Financial ratio analysis: the analysis of quantitative indicators of the financial health of the organization; these ratios depict liquidity or the ability of the ALF to satisfy short-term obligations

- Financial statements: balance sheets, profit and loss account, income and expenditure accounts, cash flow statements, and other documents that formally convey information of a financial nature to interested parties concerning an enterprise; in companies, the financial statements are subject to audit opinion

- Fixed assets: business assets that have a useful life extending over more than 1 year; examples are land and buildings, plant and machinery, vehicles 
- Fixed cost: a cost that in the short termremains the same at different levels of activity; examples are rent, real estate tax, and depreciation

- Flexible budget: a budget that is flexed to recognize the difference in behavior of fixed and variable costs in relation to levels of output; total budgeted costs are changed to accord with changed levels of activity

- Floating charge: an arrangement whereby a lender to a company has a floating charge over the assets generally of the company gives the lender priority of repayment from the proceeds of sale of the assets in the event of insolvency; banks frequently take a floating charge when lending

- Format: a specific layout for a financial statement; several alternatives are often prescribed by the prevailing governing authority or law of the country in which the enterprise operates or reports its financial performance

- Functional classification: the grouping of expenses according to the operating purposes (administrative, property, and related, etc.) for which costs are incurred; revenues are also classified functionally

- Fund: a self-containing accounting entity set up to account for a specific activity

- Fund balance: the excess of assets over liabilities (i.e., net equity); an excess of liabilities over assets is known as a deficit in fund balance

- Funded debt: also known as long-term debt

- Funded depreciation: the setting aside of a portion of retained earnings in a special account to be used for the purpose of new or replacement capital assets

- Funds flow statement: a financial statement that links balance sheets at the beginning and end of a period with the profit and loss (P\&L) account for that period;replaced by the cashflow statement

Gearing: also known as leverage, the relationship between debt and equity in the financing structure of a company

General ledger: a book that summarizes all journal entries for an accounting period in order to arrive at a trial balance

- Generally accepted accounting principles (GAAP): combination of authoritative standards (set by expert boards) and the commonly accepted ways of recording and reporting accounting information

Goal congruence: the situation in which each individual, in satisfying his or her own interests, is also making the best possible contribution to the objectives of the enterprise

- Going concern: the accounting convention that assumes that the enterprise will continue in operational existence for the foreseeable future; this means in particular that the profit and loss (P\&L) account and balance sheet assume no intention or necessity to liquidate or curtail significantly the scale of operation

Goodwill: an intangible asset that appears on the balance sheet of some businesses; $i$ is valued at (or below) the difference between the price paid for a whole business and the fair value of the net assets acquired

- Gross: usually means before or without deductions, for example, gross salary or gross profit

- Gross income: gross receipts of the assisted living facility before deductions or expenditures

Gross margin: (or gross profit ratio), gross profit expressed as a percentage of sales 
- Gross profit: sales revenue less cost of sales but before deduction of overhead expenses; in a manufacturing company, it is sales revenue less cost of sales but before deduction of nonmanufacturing overhead

- Group: a set of interrelated companies usually consisting of a holding company and its subsidiary and sub-subsidiary companies

- Group accounts: the financial statements of a group wherein the separate financial statements of the member companies of a group are combined into consolidated financial statements

- Historical cost: the accounting convention whereby goods, resources, and services are recorded at cost; cost is defined as the exchange or transaction price; under this convention, realizable values are generally ignored; inflation is also ignored; the almost universal adoption of this convention makes accounting harder to understand and lessens the credibility of financial statements

- Hurdle: a criterion that a proposed capital investment must pass before it is accepted; it may be a certain interest rate, a positive net present value (NPV), or a maximum payback period

- Income and expenditure account: the equivalent to profit and loss (P\&L) accounts in nonprofit organizations such as clubs, societies, and charities

- Indirect costs: costs that cannot be traced to particular products; an example is rent or management salaries; these are usually shared by more than one product and are called overhead

- Insolvency: the state of being unable to pay debts as they fall due; also used to describe the activities of practitioners in the fields of bankruptcy, receivership, and liquidations

- Intangible assets: assets that have long-term value but no physical identity; examples are goodwill, patents, trademarks, and brands

- Interim dividend: a dividend paid during a financial year, generally after the issue of un-audited profit figures halfway through the year

- Interim financial statements: financial statements prepared at a date other than the end of the fiscal year (e.g., monthly/quarterly balance sheets and income statements)

- Internal rate of return: the rate of discount that will just discount the future cash flows of a proposed capital investment back to the initial outlay

- Inventory: a detailed list of things; used by accountants as another word for stock

- Inventory turnover: the cost of supplies used divided by the average inventory for the period

- Invested capital: equity capital that is supplied by the owner(s) or shareholders of the assisted living community

- Investment appraisal: the use of accounting and mathematical methods to determine the likely returns for a proposed investment or capital project

- Invoice: a document portraying the details of a sale

- Journal: the book of original entry

- Labor-hour rate: a method of absorption in which the costs of a cost center are shared amongproducts on the basis of the number of hours of direct labor used on each product

- Lease: a contract in which the lessee (user) pays the lessor (owner) for the use of an asset

- Ledger: the collection of all accounts used in the assisted living facility

- Leverage: another word for gearing 
- Lien: a claim on particular property for payment of a debt or obligation

- LIFO (last in, first out): a valuation method for fungible items in which the newest items are assumed to be used first; this means stocks will be valued at old prices

- Limited liability company (LLC): a flexible form of enterprise that blends elements of partnership and corporate structures

- Limited partnership: similar to general partnership, but a framework for investors who do not want to be personally liable (as with the sole proprietorship or general partnership) for all activity of a business, but want to invest and be exposed only to the extent of their investment

Line of credit: an arrangement whereby a financial institution commits itself to lend the assisted living facility a specified maximum amount for a specified period of time

- Liquidation: the procedure whereby a company is closed, its assets realized and the proceeds divided amongst the creditors and shareholders

- Liquidity: the ease with which funds can be raised by the sale of assets

- Liquidity ratios: ratios that purport to indicate the liquidity of a business; these ratios provide information about the assisted living facility's ability to meet its short-term financial obligations; they are of particular interest to those financial institutions extending short-term credit (i.e., bank loans) to the facility; two frequently used liquidity ratios are the current ratio (or working capital) ratio and the quick ratio

- Long-term investments: investments, generally in securities, that the assisted living facility intends to own for longer than 1 year or more from the balance sheet

- Long-term liabilities: debts and obligations of the assisted living facility not due for more than 1 year or more

Management accounting: the provision and interpretation of information that assists management in planning, controlling, decision making, and appraising performance

- Management by exception: control and management of costs and revenues by concentrating on those instances where significant variances by actual from budgets have occurred

- Margin of safety: the excess of budgeted activity over break-even activity; usually expressed as a percentage of budgeted activity

Marginal cost: the additional cost incurred by the production of one extra unit

- Marginal costing: a system of cost analysis that distinguishes fixed costs from variable costs

- Marginal return: the point at which income equals expenses; it is also referred to as the break-even point

- Matching convention: the idea that revenues and costs are accrued, matched with one another as far as possible so far as their relationship can be established or justifiably assumed, and dealt with in the profit and loss (P\&L) account of the period in which they relate; an example is the matching of sales of a product with the development costs of that product; the appropriate periods would be when the sales occur

- Master budgets: the overall budgets of an enterprise comprising cash budget, forecast profit and loss (P\&L) account and forecast balance sheet (BS); they are made from subsidiary budgets

- Material management: the integration of the processes of planning, acquiring, moving, and controlling materials 
Materiality: the accounting convention that recognizes that accounting is a summarizing process; some items and transactions are large (i.e., material) enough to merit separate disclosure rather than inclusion with others in a lump sum; examples are an exceptionally large bad debt or an exceptionally large loss on sale of a fixed asset

- Minority interest: the interests in the assets of a group relating to shares in group companies not held by the holding company or other members of the group

- Modified accounts: financial statements that are shortened versions of full accounts; smalland medium-sized companies can file these with the Registrar of Companies instead of full accounts

- Money measurement: the convention that requires that all assets, liabilities, revenues, and expenses shall be expressed in monetary terms

- Mortgage: a pledge of designated property as security for a loan (e.g., mortgage bonds)

- National Investment Center for Senior Housing (NIC): established in 1991 to enable access and choice in seniors housing and care by collecting data and providing analytics that investors and operators need to make informed decisions

- Natural expense classification: a method of classifying expenditures according to their natural classification such as salaries, utilities, and supplies

- Net: usually means after deductions

- Net book value: the valuation on the balance sheet of an asset; also known as the carrying value or written down value

- Net income: the excess of revenue over related expenses during an accounting period

- Net present value: the value obtained by discounting all cash inflows and outflows attributable to a proposed capital investment project by a selected discount rate

- Net realizable value: the actual or estimated selling price of an asset less all further costs to completion (e.g., cost of a repair if it needs to be repaired before sale) and all costs to be incurred before and on sale (e.g., commission)

- New worth: can be calculated by total assets minus total liabilities

- Nominal value: the face value of a share or debenture as stated in the official documents; usually will not be the same as the issue price, which may be at a premium and that will almost never correspond to actual value

- Objectivity: the convention of using reliable and verifiable facts (e.g., the input cost of an asset) rather than estimates of 'value' even if the latter is more realistic

- Occupancy rate: a key utilization measurement of success for assisted living facilities that is the ratio of actual number of resident days to the total possible resident days

- OpCo/PropCo: a common industry vernacular referring to the idea that owners will separate the property interest in a separate legal entity ("prop-co") from the ownership of the ongoing business operations ("op-co") for added liability protection

- Operating budget: includes anticipated incomes by source and anticipated expenses by category

- Operating cycle: the period of time it takes a firm to buy inputs, make or market a product and sell to and collect the cash from a customer

- Operating ratio: total operating expenses divided by total operating revenues

- Opportunity cost: the value of a benefit sacrificed in favor of an alternative course of action 
Outsourcing: the use of services (such as administration or computing) from separate outside firms instead of using the enterprise's own employees

- Overheads: indirect cost

- Partnership: when two or more persons (or entities) wish to work on a venture together and the profits and losses are shared proportionally

- Payback: the number of years that will elapse before the total incoming cash receipts of a proposed project are forecast to exceed the initial outlays

- Periodicity: the convention that financial statements are produced at regular intervals usually at least annually

- Petty cash fund: a small fund of cash maintained by the assisted living facility for the purpose of making minor disbursements (e.g., less than $\$ 25$ or \$50) for which the issuance of a bank check is impractical

- Physical inventory: the actual inventory as determined by physical count by auditors, usually at the end of a reporting period (usually annually)

- Planning variance: a variance arising because the budgeted cost is now seen as out of date; examples are wage or price rises

- Pledging of receivables: the use of resident account receivables as security or collateral for a bank loan

- Position control plan: a management tool for controlling the number of employees on the assisted living facility payroll and for assuring the utilization of each employee to the point of maximum effectiveness; also known as a staffing plan

- Posting: a transfer from the general journal to the ledger

- Prepayments: expenditure already made on goods or services but where the benefit will be felt after the balance sheet (BS) date; examples are rent or rates or insurances paid in advance

- Price earnings ratio: an investor ratio calculated asshare/earnings per share

- Private company: any company that is not a public company

- Profit and loss (P\&L) account: a financial statement thatmeasures and reports the profit earned over a period of time

- Profitability index: in investment appraisal, the net present value of cash inflows/the initial outlays

- Profitability ratios: provides information on several different measures of success of the assisted living facility at generating profits; two key profitability ratios are the return on assets ratio and the return on equity ratio

- Provision: a charge in the profit and loss (P\&L) account of a business for an expense that arose in the past but which will only give rise to a payment in the future; to be a provision the amount payable must be uncertain as to amount or as to payability or both; an example is possible damages awardable by a court in a future action over a past incident (e.g., a libel)

- Prudence (or conservatism): the convention whereby revenue and profits are not anticipated, but provision is made for all known liabilities (expenses and losses) whether the amount of these is known with certainty or is a best estimate;essentially: future profit, wait until it happensfuture loss, count it now

- Publicly traded: a company whose ownership is made up of shares of stock that are publicly traded on one of several stock exchanges or "over-the-counter" markets 
- Purchase order: document issued by the assisted living community authorizing a vendor to deliver goods with payment to be made later

- Qualified audit report: an audit report including one or more qualifications or exceptions

- Quantity discount: a reduction in unit purchase cost received by those who acquire supplies in a quantity in excess of a specific amount

- Quick ratio: also known as acid test ratio, current assets (except stock)/current liabilities

- Real estate investment trust (REIT): a legal entity that will raise large amounts of funds for owning large portfolios of property and then lease large portions of their portfolios to various larger operating companies

- Realizable value: the amount that an asset can be sold for

- Realization: to sell an asset and hence turn it into cash

- Realization convention: the concept that a profit is accounted (or when a good is sold and not when the cash is received)

- Receiver: an insolvency practitioner who is appointed by a debenture holder with a fixed or floating charge when a company defaults

Reconciliation: the procedure of checking bank accounts, deposits, and withdrawals against the bank statement

- Redemption: repayment of shares, debentures, or loans

- Redemption yield: the yield given by an investment expressed as a percentage and taking into account both income and capital gain or loss

- Reducing balance: a method of depreciation whereby the asset is expensed to the profit and loss (P\&L) account over its useful life by applying a fixed percentage to the written-down value

- Relevant costs: costs that will only be incurred if a proposed course of action is actually taken; the only ones relevant to an actual decision

- Relevant range: the range of activity that is likely; within this range, variable costs are expected to be linearly variable with output and fixed costs are expected to be unchanged

- Reporting: the process whereby a company or other institution seeks to inform shareholders and other interested parties of the results and position of the entity by means of financial statements

- Reserves: a technical term indicating that a company has total assets which exceed in amount the sum of liabilities and share capital; this excess arises from retained profits or from revaluations of assets

- Resource accounting and budgeting: the use of normal accruals accounting and balance sheets in federal/government departments and agencies

- Responsibility accounting: a system of accounting which accumulates financial and statistical information according to the organizational units generating the revenues and responsible for incurring the expenses; the primary purpose is to obtain optimal financial management control

- Retained profits: also known as retentions, the excess of profits over dividends

- Return on capital employed: a profitability ratio being income expressed as a percentage of the capital that produced the income

- Return on sales: the ratio of profit to sales expressed as a percentage 
- Returns: the income flowing from the ownership of assets; may include capital gains

- Revenue: amounts charged to customers for goods or services rendered

- Revenue expenditure: expenditure that benefits only the current period and which will therefore be charged in the profit and loss (P\&L) account

- ROP: known as the reorder point; in inventory management, the point in time at which a new order should be placed for supplies and/or services

- Safe harbor regulations: federal regulations describing investment interest and other business transactions that are not violations of the Medicare and Medicaid antifraud and abuse laws

- Salvage value: also known as residual value, the amount estimated to be recoverable from the sale of a fixed asset at the end of its useful life

- Secured liabilities: liabilities secured by a fixed or floating charge or by other operation of law such as hire purchase commitments

- Securities: financial assets such as shares, debentures, and loan stocks

- Shareholder: individuals or entities that own shares of corporation's stock

- Single asset entity: a legal entity formed to hold a single asset, not multiple, such as when organizations hold the real estate and the operations together

- Sinking fund: funds required by external sources to be set aside to meet debt service charges and the retirement of indebtedness on plant assets

- Sole proprietorship: a business ownership form, usually for smaller concerns, with a single owner, in which the owner as an individual is not separate from the business

- State of changes in financial position: a financial statement summarizing the movement of funds (working capital) within the assisted living facility for a given period of time

- Stockholder's equity: the excess of assets over liabilities that consists mainly of invested capital and retained earnings

- Subchapter $\mathrm{S}$ corporation: a corporation that is taxed by the Internal Revenue Service as a private individual

- Subsidiary ledger: a group of accounts that is contained in a separate ledger that supports a single account (a control account) in the general ledger

- Tangible asset: an asset that has physical characteristics as equipment, land, and buildings

- Third-party payer: someone else paying for the ALC bill other than the resident; it could either be a commercial insurance company that offers long-term care insurance or state Medicaid; Medicare generally does not pay for assisted living facility's expenses

- Trial balance: a financial statement indicating name and balance of all ledger accounts arranged according to whether they are debts or credits; debits must equal credits

- Turnover ratios: financial indicators that measure the efficient management of assets by indicating the number of times assets (inventories, accounts receivables, etc.) are replaced during a period

Useful life: an estimate of the number of years an item of plant and equipment will be used by the assisted living facility

Variable cost: an operating cost that varies in direct proportion to change in volume; examples are salary costs, supplies, etc. 
- Variance analysis: managerial control technique that identifies deviations from the original budget projections

- Voucher system: a system for the processing and control of cash disbursements

- Weighted-average costing: a method that determines the cost of supplies used and the valuation of inventory

- Working capital: available excess assets left over from subtracting current assets from current liabilities that the assisted living community can use in operations

Write off: the removal of a bad debt from revenues that reduces its value to zero; an example is resident room and board charges that are written off because of nonpayment after failure of collection efforts by the ALC

- Yield: the actual rate of return on an investment as opposed to the nominal rate of return 